\title{
Effect of Extracts of the Aerial Parts and Roots from Four Ferulago Species on Erectile Dysfunction in Rats with Streptozotocin-Induced Diabetes
}

\author{
Streptozotosin ile Oluşturulan Diyabetik Sıçanlarda Dört Ferulago \\ Türünün Toprak Üstü ve Kök Ekstrelerinin Erektil Disfonksiyon Üzerine \\ Etkisi
}

\author{
(D) Songül KARAKAYA ${ }^{*}$, (D) Didem YILMAZ ORAL2 (D) Serap GÜR², (D) Hayri DUMAN³, (D) Ceyda Sibel KILIÇ4 \\ ${ }^{1}$ Atatürk University, Faculty of Pharmacy, Department of Pharmacognosy, Erzurum, Turkey \\ 2Ankara University, Faculty of Pharmacy, Department of Pharmacology, Ankara, Turkey \\ 3 Gazi University, Faculty of Science, Department of Biology, Ankara, Turkey \\ ${ }^{4}$ Ankara University, Faculty of Pharmacy, Department of Pharmaceutical Botany, Ankara, Turkey
}

\begin{abstract}
Objectives: The extracts of Ferulago species are used as aphrodisiacs in Turkey and so we aimed to demonstrate in vivo and in vitro the relaxant effect of four Ferulago species' extracts on the corpus cavernosum (CC).

Materials and Methods: A total of 30 adult male Sprague Dawley rats were divided into control and diabetic groups. Diabetes was induced by a single intraperitoneal injection of $40 \mathrm{mg} / \mathrm{kg}$ streptozotocin. In vivo erectile responses were obtained by stimulation of the cavernosal nerves and repeated after intracavernosal injection of extracts in rats, and the data were expressed as intracavernosal pressure (ICP)/mean arterial pressure and total ICP. The relaxant and contractile responses of CC strips were analyzed in the presence or absence of extracts.

Results: The extracts were active in both control and diabetic rats. The extract-induced maximum relaxation responses (especially of methanol extract of the root of Ferulago bracteata) $(98.30 \pm 2.6 \%)$ were decreased after incubation with L-NAME (44.8 \pm 1.8$)$. ODQ, a soluble guanylate cyclase inhibitor, inhibited $77 \%$ of extract-induced maximum relaxation in the $\mathrm{CC}$ from the control rats.

Conclusion: These species can be utilized in erectile dysfunction and may be an herbal alternative to synthetic drugs.
\end{abstract}

Key words: Aphrodisiacs, Apiaceae, Ferulago, erectile function

Öz

Amaç: Ferulago türlerine ait ekstreler Türkiye'de afrodizyak olarak kullanılmaktadır, bu nedenle in vivo ve in vitro olarak dört Ferulago türüne ait ekstrelerin korpus kavernosum (CC) üzerindeki gevşetici etkisini göstermeyi amaçladık.

Gereç ve Yöntemler: Kontrol ve diyabetik gruba ayrılan toplam 30 yetişkin erkek Sprague Dawley sıçanı, 40 mg/kg Streptozotocin ile intraperitonal olarak tek seferlik enjeksiyon ile indüklenmiştir. Kavernosal sinirlerin uyarılmasıyla in vivo erektil yanıtlar elde edildi ve sıçanlarda intrakavernozal ekstraktların enjeksiyonu sonrasında tekrarlandı ve veriler intrakavernozal basınç (ICP)/ortalama arteriyel basınç ve toplam ICP olarak ifade edildi. CC striplerin gevşetici ve kasılma yanıtları, ekstraktların varlığında veya yokluğunda analiz edildi.

Bulgular: Ekstraktların hem kontrol hem de diyabetik sıçanlar üzerinde aktif olduğu bulundu. Ekstraktlar (özellikle Ferulago bracteata kök metanol

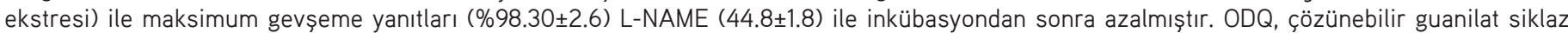
inhibitörü, kontrol sıçanlarından CC'de ekstraktların indüklediği maksimum gevşemenin \%77'sini inhibe ettiği görülmüştür.

Sonuç: Sonuç olarak bu türler erektil disfonksiyonda kullanılabilir ve sentetik ilaçlara karşı bitkisel alternatif oluşturabilir.

Anahtar kelimeler: Afrodizyak, Apiaceae, Ferulago, erektil disfonksiyon

*Correspondence: E-mail: ecz-songul@hotmail.com, Phone: +90 4422315250 ORCID-ID: orcid.org/0000-0002-3268-721X

Received: 14.03.2018, Accepted: 07.06.2018

๑Turk J Pharm Sci, Published by Galenos Publishing House. 


\section{INTRODUCTION}

Diabetes is one of the most prevalent causes of erectile dysfunction (ED), which eminently influences the quality of life, and the risk of developing ED in diabetic men is threefold higher than that in healthy men., ${ }^{1,2}$ As compared with the other complications of diabetes, the development of ED begins at an earlier age. Moreover, the incidence and severity of ED increase with the duration of diabetes ${ }^{3}$ and multifactorial mechanisms including neurogenic and vasculogenic factors are involved in diabetic ED. The efficacy of some ED treatments is limited for diabetes-associated ED. For example, men with diabetes frequently show a poor response to first-line oral phosphodiesterase type 5 (PDE-5) inhibitors. ${ }^{4}$ An alternative therapy choice may be phytotherapy for diabetic ED.

In the present study, we examined the effect of lyophilized aqueous and methanol extracts of Ferulago species growing naturally in Turkey on erectile tissue. In Turkey these species are known as "çağşır" or "çakşır" and are utilized conventionally as an aphrodisiac in South and Southeast Anatolia. Actually, many species that belong to the genera Ferulago, Prangos, and Ferula have been utilized for this aim. These species are utilized in rutting of goats and sheep, and water decoctions of the roots and aerial parts are administered orally as aphrodisiacs. ${ }^{5}$ In Turkey Ferulago species are usually well known for their aphrodisiac activities like various plants in other countries. ${ }^{6}$ Apart from their medicinal usage, they have been consumed in salads or as spices due to their special odor, and used as food for goats and deer. ${ }^{7}$

Ferulago W. Koch. (Apiaceae) is represented by 34 taxa in Turkey, 19 of which are endemic. For this reason Anatolia is considered to be the gene center of this genus. ${ }^{8}$ Ferulago blancheana Post ex Boiss., Ferulago pachyloba (Fenzl) Boiss. and Ferulago bracteata Boiss. \& Hausskn. are endemic perennial species growing only in Kayseri, Central Anatolia; Niğde, Central Anatolia; and Gaziantep, Southeastern Anatolia, Turkey, respectively, but Ferulago trachycarpa Boiss. is not an endemic species, growing in Antalya. ${ }^{9}$ During our studies, we found that aqueous and methanol extracts of the roots and aerial parts from Ferulago species produced relaxation in precontracted rat corpus cavernosum (CC). Therefore, we planned to investigate the pharmacological profile of their relaxant effect by using isolated CC tissue in vivo and in vitro. This study aims to give the first report to evaluate the effect of extracts from $F$. blancheana, $F$. pachyloba, F. trachycarpa, and F. bracteata on ED in rats with streptozotocin (STZ)-induced diabetes.

\section{MATERIALS AND METHODS}

\section{Plant material}

Flowering plants of $F$. blancheana, F. pachyloba, F. trachycarpa, and $F$. bracteata were collected in 2014 from Kayseri, Niğde, Antalya, and Gaziantep (Turkey), respectively, and identified by Prof. Dr. Hayri Duman, a plant taxonomist at the Department of Biology, Faculty of Science, Gazi University. The voucher specimens are kept in the Herbarium of Ankara University, Faculty of Pharmacy (herbarium numbers AEF 26673, AEF 26674, AEF 26677, and AEF 26676, respectively).

\section{Extraction}

The air-dried roots and aerial parts of these species were powdered and macerated three times with methanol for $8 \mathrm{~h}$ in a water bath not exceeding $45^{\circ} \mathrm{C}(3 \times 200 \mathrm{~mL})$ using a mechanical mixer at $300 \mathrm{rpm}$, separately. The extracts were filtered and concentrated until dryness by rotary evaporator (Heidolph VV2000, Germany). Moreover, $50 \mathrm{~g}$ of roots and aerial parts from these plants were ground and macerated with $200 \mathrm{~mL}$ of distilled water for $8 \mathrm{~h} / 3$ days at 30 to $35^{\circ} \mathrm{C}$, separately. The aqueous extract was filtered, frozen (Sanyo Medical Freezer, Germany), and lyophilized (Christ ${ }^{\circledR}$ Gamma 2-16 LSC, Germany) to give aqueous extracts from the roots and aerial parts. The amounts of the powdered plants and extracts obtained are given in Table 1.

\section{Animals}

Adult male Sprague Dawley rats (350-400 g) received a dose of streptozotocin (STZ, $40 \mathrm{mg} / \mathrm{kg}$, i.p.) within a citrate buffer ( $\mathrm{pH}$ 5.5) on the day of use. ${ }^{10}$ Measurement of blood glucose levels was carried out using an Accu-Chek glucometer (Roche Diagnostics, Indianapolis, IN, USA) after the induction of diabetes. The animals were housed in separate cages on a 12-h light-dark cycle and were fed standard water and chow ad libitum. This study was approved by the Institutional Animal Care and Use Committee of Ankara University (2014-15-86).

\section{In vivo assessment of erectile function}

To assess erectile function in vivo, intracavernosal pressure (ICP) (ICP, mmHg) was monitored in the rats. The rats were anesthetized with ketamine $(50 \mathrm{mg} / \mathrm{kg}$, i.p.) and the trachea was cannulated [polyethylene, (PE)-240 tubing] to keep the airway open, and the carotid artery was cannulated (PE-50 tubing) to measure the main arterial pressure (MAP, $\mathrm{mmHg}$ ), by a transducer (Statham, Oxnard, CA, USA) attached to a data acquisition system (Biopac MP 100 System, Santa Barbara, CA, USA). A 25-gauge needle filled with $250 \mathrm{U} / \mathrm{mL}$ heparin and connected to polyethylene-50 tubing was placed in the right crus of the penis connected to a pressure transducer to measure ICP indissolubly. The right major pelvic ganglion and cavernosal nerve (CN) were represented. A stainless-steel bipolar hook electrode for stimulation was installed around the $\mathrm{CN}$ postero-lateral to the prostate on one side, and the MAP

Table 1. Amounts of the powdered plants and obtained extracts

\begin{tabular}{lllll} 
Species & Used parts & $\begin{array}{l}\text { Powdered } \\
(\mathrm{g})\end{array}$ & $\begin{array}{l}\mathrm{MeOH} \\
(\mathrm{g})\end{array}$ & $\begin{array}{l}\text { Lyophilized } \\
\text { aqueous (g) }\end{array}$ \\
\hline \multirow{2}{*}{ F. blancheana } & Root & 50 & 6.62 & 5.78 \\
\cline { 2 - 5 } & Aerial part & 50 & 3.22 & 4.78 \\
\hline \multirow{2}{*}{ F. pachyloba } & Root & 50 & 7.25 & 6.98 \\
\cline { 2 - 5 } & Aerial part & 50 & 3.32 & 4.01 \\
\hline \multirow{2}{*}{ F. trachycarpa } & Root & 50 & 6.77 & 7.76 \\
\cline { 2 - 5 } & Aerial part & 50 & 3.41 & 3.67 \\
\hline \multirow{2}{*}{ F. bracteata } & Root & 50 & 7.94 & 5.99 \\
\cline { 2 - 5 } & Aerial part & 50 & 3.65 & 4.88 \\
\hline
\end{tabular}


$(\mathrm{mmHg})$ and ICP $(\mathrm{mmHg})$ were indissolubly measured with pressure transducers. The CN was stimulated $(2.5,5$, and $7.5 \mathrm{~V}$, $15 \mathrm{~Hz}, 30$ s train duration) with a square pulse stimulator (Grass Instruments, Quincy, MA, USA) and electrical stimulation was inducted distally to the ligature. The measurements were repeated after intracavernosal administration of extracts $(1 \mu \mathrm{M})$ in groups. ${ }^{10}$

\section{Isometric tension measurements}

Cavernosal tissue (CC) strips were placed in organ bath chambers and maintained in Krebs-bicarbonate solution (containing, $\mathrm{mM}: \mathrm{KCl}$ 4.7, $\mathrm{NaCl}$ 118.1, $\mathrm{MgSO}_{4}$ 1.0, $\mathrm{KH}_{2} \mathrm{PO}_{4} 1.0$, $\mathrm{NaHCO}_{3} ; 25.0$, glucose 11.1, and $\mathrm{CaCl} 22.5, \mathrm{pH} 7.4$ ). The strips $\left(1 \times 1 \times 9 \mathrm{~mm}^{3}\right)$ were dissected and combined under $1 \mathrm{~g}$ of resting tension in a $20 \mathrm{~mL}$ organ bath. The organ chamber temperature was kept at $37^{\circ} \mathrm{C}$ by a circulating water bath and continuous bubbling with a mixture of $95 \% \mathrm{O}_{2}$ and $5 \% \mathrm{CO}_{2}$. The tissues were permitted to equilibrate for a minimum of $60 \mathrm{~min}$, and the bath solution was changed every 15 min. Electrical field stimulation (EFS) of the autonomic nerves (duration: $15 \mathrm{~s}$; amplitude: $50-$ $90 \mathrm{~V}$; frequency: pulse width: $5 \mathrm{~ms}$ ) was achieved by the use of platinum electrodes, placed on either side of the tissue strip (Grass Instruments, Quincy, MA, USA).

In the first series of trials, CC strips were precontracted with phenylephrine (Phe, $10^{-5} \mathrm{M}$ ) and allowed to relax after administration of the extracts. The relaxation response curves to the extracts were also acquired in the presence of the nonspecific nitric oxide (NO) synthase inhibitor L-NAME (L-N(G)-nitroarginine methyl ester, $100 \mu \mathrm{M}$ ) and soluble guanylate cyclase inhibitor ODQ (1H-[1,2,4]-oxadiazolo[4,3-a] quinoxaline-1-one, $30 \mu \mathrm{M}$ ).

In the second series of trials, acetylcholine (ACh)-, EFS-, sildenafil-, and sodium nitroprusside (SNP)-induced relaxation responses were stimulated after precontraction of CC strips with Phe $\left(10^{-5} \mathrm{M}\right)$ in the presence or absence of the extracts $(100 \mu \mathrm{M})$.

\section{Statistical analysis}

All results are expressed as mean \pm standard error and differences between means were statistically analyzed using one-way ANOVA followed by Bonferroni's complementary analysis, with p<0.05 considered to indicate statistical significance. At the end of the experiment, each CC strip was weighed. All contractile responses were expressed as $\mathrm{mg}$ of tension developed per $\mathrm{mg}$ of corporal tissue and relaxant responses were calculated as a percentage of Phe-contraction.

\section{Drugs}

All drugs were purchased from Sigma Chemical Co. (St. Louis, MO, USA).

\section{RESULTS}

\section{Extraction}

Methanol and lyophilized aqueous extracts of the roots and aerial parts from Ferulago species were evaluated for their effect on ED.

\section{Characteristics of animals}

Body weight of the diabetic rats was considerably lower than that of the control rats (Figure 1a, p<0.001). Blood glucose levels in the diabetic group were considerably higher than those in the control group (Figure 1b, p<0.001).

\section{In vivo erectile responses in both groups}

ICP/MAP values in the control rats were higher than in the diabetic rats ( $p<0.001$; Figure 2), which was reversed by intracavernosal administration of the extracts $(1 \mu \mathrm{M})$. Moreover, total ICP values were decreased in the diabetic group compared with the control group ( $p<0.001$; Figure 2). After the intracavernosal administration of the extracts $(1 \mu \mathrm{M})$ total ICP values were restored in the diabetic group at all voltage levels, except for the 7.5 voltage level (Figure 2).

\section{In vitro responses of CC strips}

The extract-induced maximum relaxation responses (especially methanol extract of the roots from $F$. bracteata) $(98.30 \pm 2.6 \%)$ were decreased after incubation with L-NAME (44.8 \pm 1.8 , Figure 3a). ODQ, a soluble guanylate cyclase inhibitor, inhibited $77 \%$ of extract-induced maximum relaxation in the $\mathrm{CC}$ from the control rats (Figure 3 ).

The endothelial-dependent relaxation response to ACh (1 mM) in the control rats was higher than in the diabetic rats, which was increased after the incubation of the extracts $(100 \mu \mathrm{M})$ in the control and diabetic groups (Figure 4).
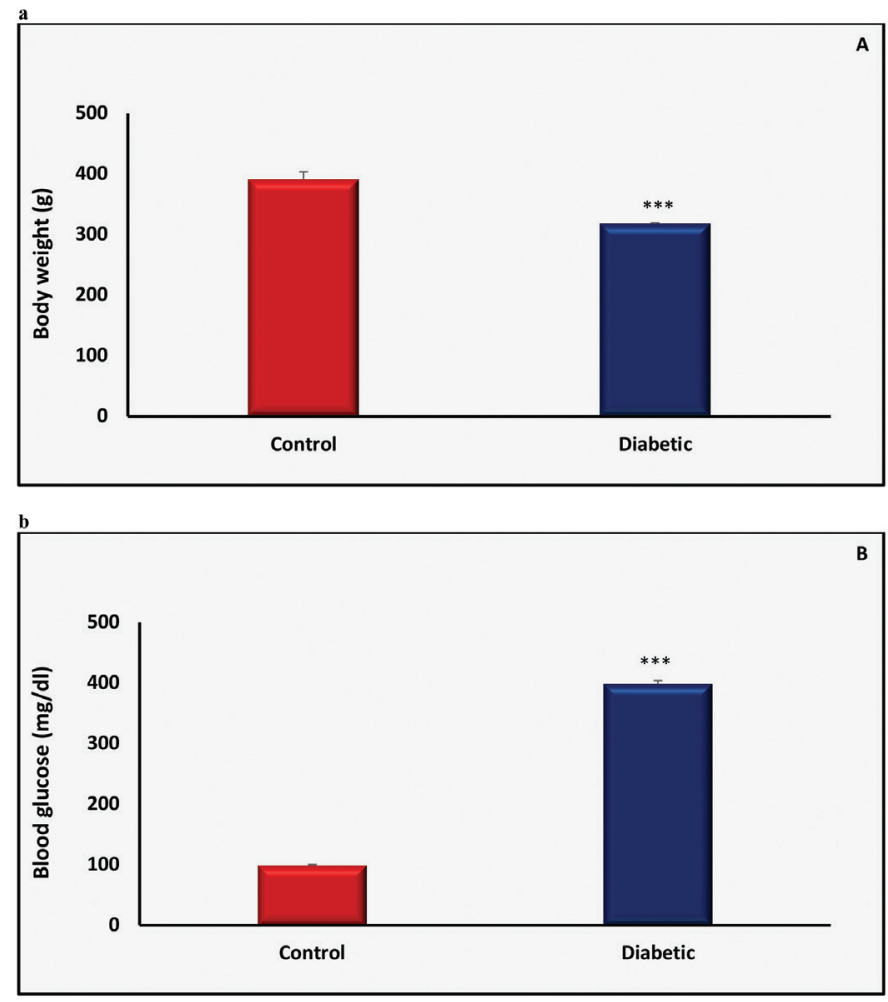

Figure 1. Bar graph showing body weight of the control and diabetic groups (a) and glucose levels (b) in the control and diabetic groups. Data are mean \pm standard error of mean $(n=6)$ and ${ }^{* * *} p<0.001$ vs control 
EFS-induced relaxation response at $20 \mathrm{~Hz}$ was decreased in the diabetic group compared with the control group, which was restored by the incubation with the extracts $(100 \mu \mathrm{M})$. There was no difference in EFS-induced relaxation response in the control rats between the presence and absence of the extracts (Figure 5).

SNP-induced endothelial-independent relaxation response at $0.1 \mu \mathrm{M}$ dose relaxation was not different in the control rats when compared with the diabetic rats (Figure 6). However, relaxation responses to SNP were enhanced in the presence of the extracts $(100 \mu \mathrm{M})$ in the diabetic and control rats.

The relaxation response induced by the PDE-5 inhibitor sildenafil at $1 \mu \mathrm{M}$ dose was considerably reduced in the diabetic rats when compared with the control rats (Figure 4d). After incubation of the extracts $(100 \mu \mathrm{M})$, relaxation responses to sildenafil were higher in the diabetic and control rats (Figure 7).

\section{DISCUSSION}

In the present study, we aimed to examine the relaxant effect of methanol and lyophilized aqueous extracts of the roots and aerial parts of $F$. blancheana, F. pachyloba, F. trachycarpa, and $F$. trachycarpa in the CC with in vivo and in vitro studies. Corporal smooth muscle relaxation plays a significant role in erection. Smooth muscle relaxation, which is interceded by NO throughout sexual stimulation, is synthesized in the nerve terminals of parasympathetic noncholinergic and nonadrenergic nerves in the penis as well as by the endothelial cells lining the blood vessels and lacunar spaces of the CC.11

The first data provide basic mechanistic information concerning the extract-induced dose-dependent relaxation in rat $\mathrm{CC}$. The major findings of the study show that (i) the extracts relax rat $\mathrm{CC}$ in a concentration-dependent manner; (ii) the NO-cGMP pathway plays an important role in mediating extract-induced relaxation; and (iii) they partially restore in vivo erectile function in diabetic rats.

Penile erection in response to $\mathrm{CN}$ stimulation was confirmed in vivo in a diabetic animal model. Our data showed that diabetes reduced the in vivo erectile response and the in vitro relaxant response of the CC to EFS. Amazingly, erectile responses (ICP) MAP and total ICP) gained after cavernous nerve stimulation except $7.5 \mathrm{~V}$ were augmented in the extract-injected diabetic group, as compared with the vehicle-injected diabetic group. In in vitro studies, the nitrergic relaxation response to EFS in the diabetic rats was increased by the incubation of extracts. There were no previous data to evaluate the effect of these species on erectile function. However, the extract treatment reduced the diabetes-induced renal damage related to the diabetic nephropathy. ${ }^{12}$ Moreover, the treatment improved the activities of enzymatic and nonenzymatic antioxidants, ${ }^{13}$ and also in vitro increased the glycolytic activities. ${ }^{14}$ These results indicate a rationale for more studies using combinations of extracts and phosphodiesterase-5 inhibitors in diabetes-induced ED.

The present study showed that extract-induced relaxation in the $\mathrm{CC}$ from the diabetic group was not changed compared with that from the control group. The data support the intracavernosal administration of extracts to augment erectile responses. It seems that the extract responses serve as the normal activity in

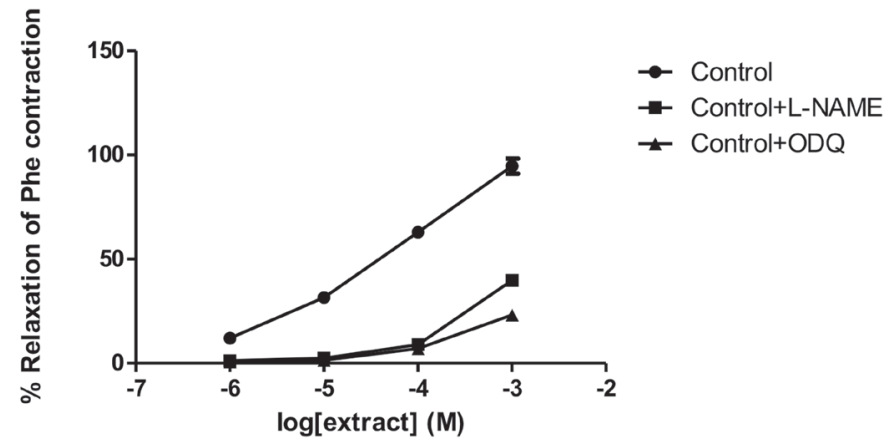

Figure 3. Concentration-response curves to extract $\left(10^{-6}-10^{-3} \mathrm{M}\right)$ in the corpus cavernosum after precontraction with phenylephrine (Phe, $10 \mu \mathrm{M}$ ) in the presence of L-NAME $(100 \mu \mathrm{M}, \mathrm{A})$ and $\mathrm{ODQ}(30 \mu \mathrm{M}, \mathrm{B})$. Data represent mean \pm standard error of mean of $6-8$ observations. ${ }^{* \star} p<0.001$ vs control value
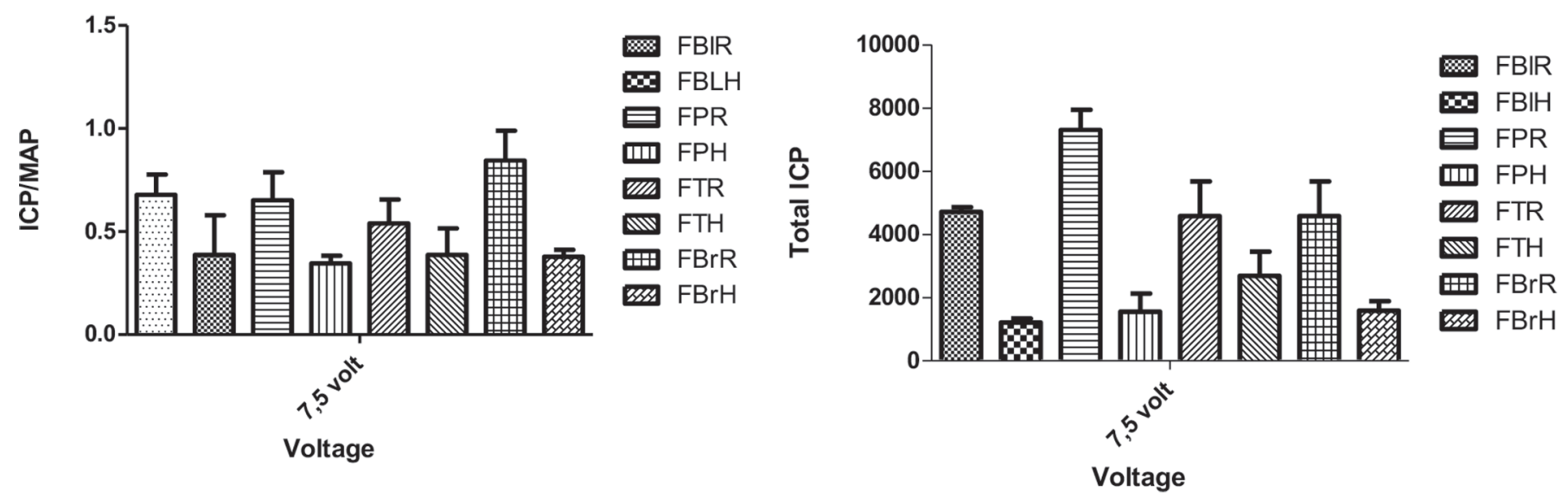

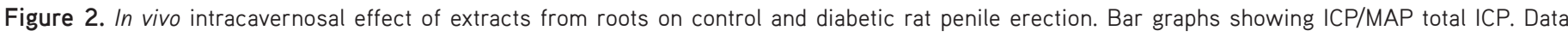
represent mean \pm standard error of mean of $6-8$ observations $(p=0.1413$ )

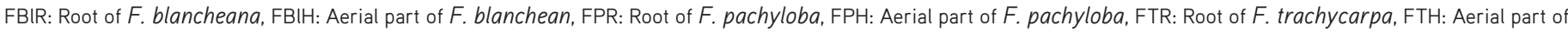
F. trachycarpa, FBrR: Root of F. bracteata, $\mathrm{FBrH}$ : Aerial part of $F$. bracteate, ICP: Intracavernosal pressure, MAP: Mean arterial pressure 
vivo and in vitro in diabetes. Moreover, relaxation to the extracts was calmly inhibited after precontraction with $\mathrm{KCl}$. Potential sensitive calcium channels are forced by depolarization of the plasma membrane when the extracellular $\mathrm{K}^{+1}$ concentration is augmented. Potential sensitive calcium channels were activated by depolarization of the plasma membrane when the extracellular $\mathrm{K}+$ concentration was enhanced.
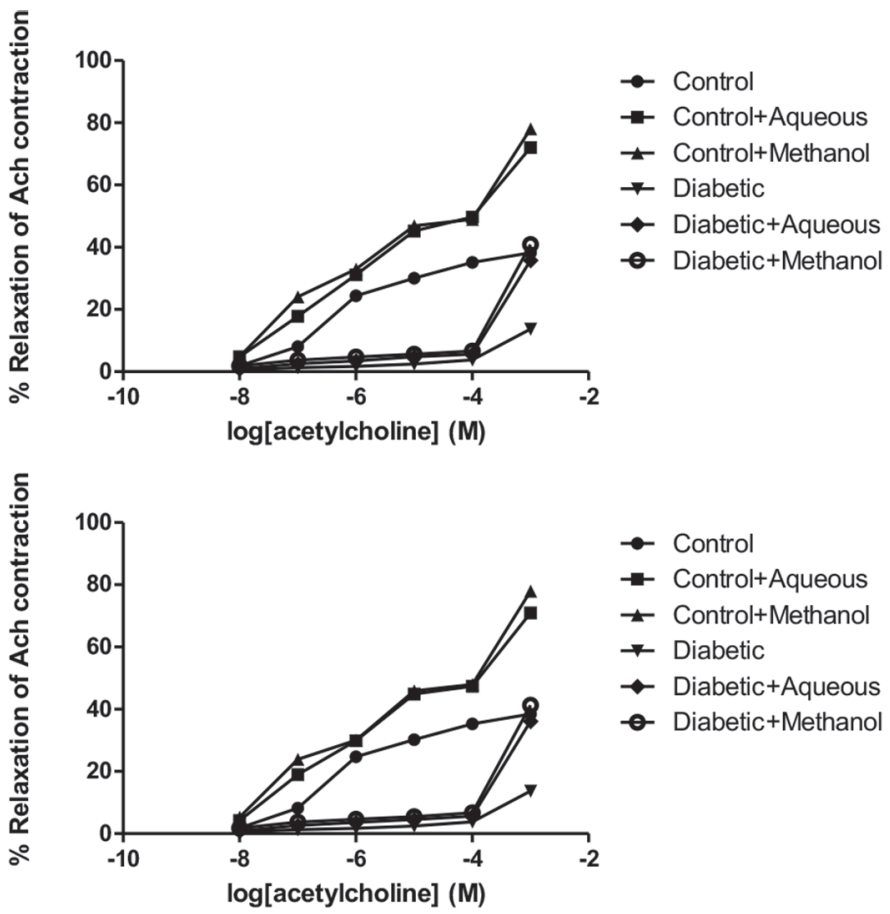

$\rightarrow$ Control
$\rightarrow$ Control+Aqueous
$\leftarrow$ Control+Methanol
$\rightarrow$ Diabetic
$\leftarrow$ Diabetic+Aqueous
- Diabetic+Methano
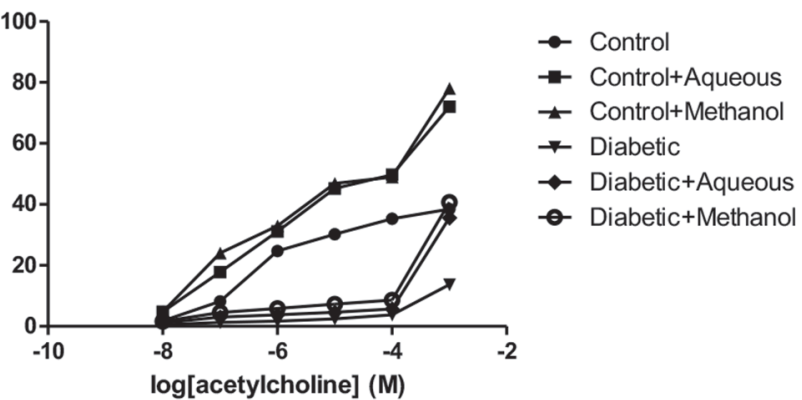

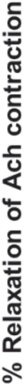
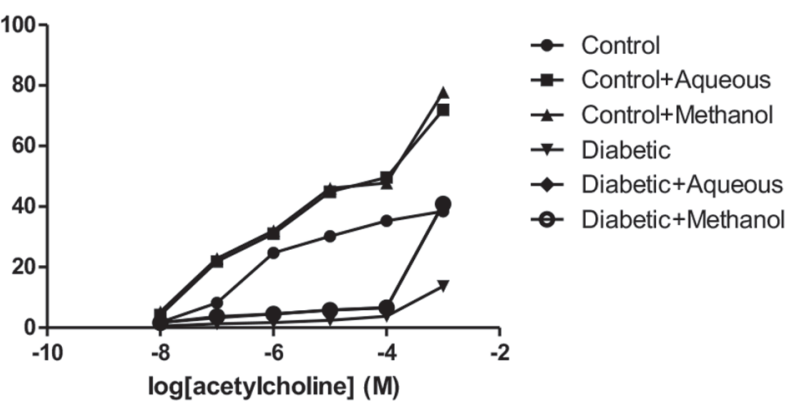

In the current study, we researched the underlying mechanism of the extracts' effects on erectile responses that can be mediated by the NO/cGMP-dependent pathway, which is damaged in diabetes. No earlier study appears to have been done on the mechanism of the extracts in penile tissue. The extracts are most likely to have a role in the NO-cGMP signaling pathway, mediating $\mathrm{CC}$ relaxation responses.
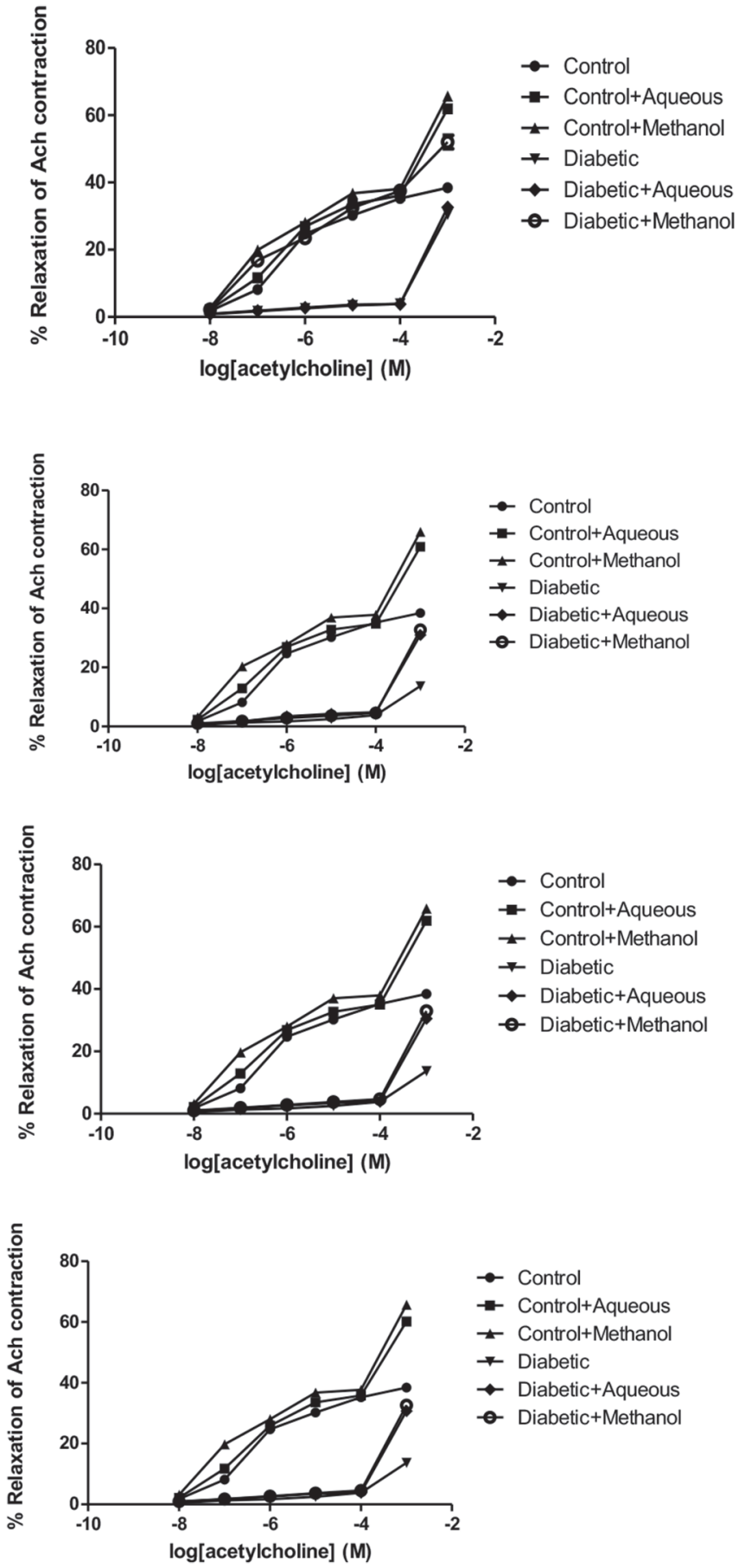

Figure 4. Relaxation responses to single doses of ACh in the presence of extract of FBIR, FBIH, FPR, FPH, FTR, FTH, FBrR, and FBrh, respectively. Data represent mean \pm standard error of mean of $6-8$ observations. ${ }^{*} p<0.05,{ }^{* * *} p<0.001$ vs. control value. $\S p<0.05, \S \S p<0.01$ vs diabetic value

ACh: Acetylcholine, FBIR: Root of F. blancheana, FBIH: Aerial part of F. blanchean, FPR: Root of F. pachyloba, FPH: Aerial part of F. pachyloba, FTR: Root of F. trachycarpa, FTH: Aerial part of $F$. trachycarpa, $\mathrm{FBrR}$ : Root of $F$. bracteata, $\mathrm{FBrH}$ : Aerial part of $F$. bracteate 
In the isolated CC from the diabetic group, the endotheliumdependent relaxation response to $\mathrm{ACh}$ was considerably reduced, which was potentialized in the presence of the extracts. There were no previous supporting data similar to these findings.

There was no difference in the endothelial-independent relaxation response to SNP between the control and diabetic rats, which was enhanced in the groups after incubation of the extracts. In previous studies, SNP-induced relaxant responses did not change in diabetic rats when compared with the controls. 15,16
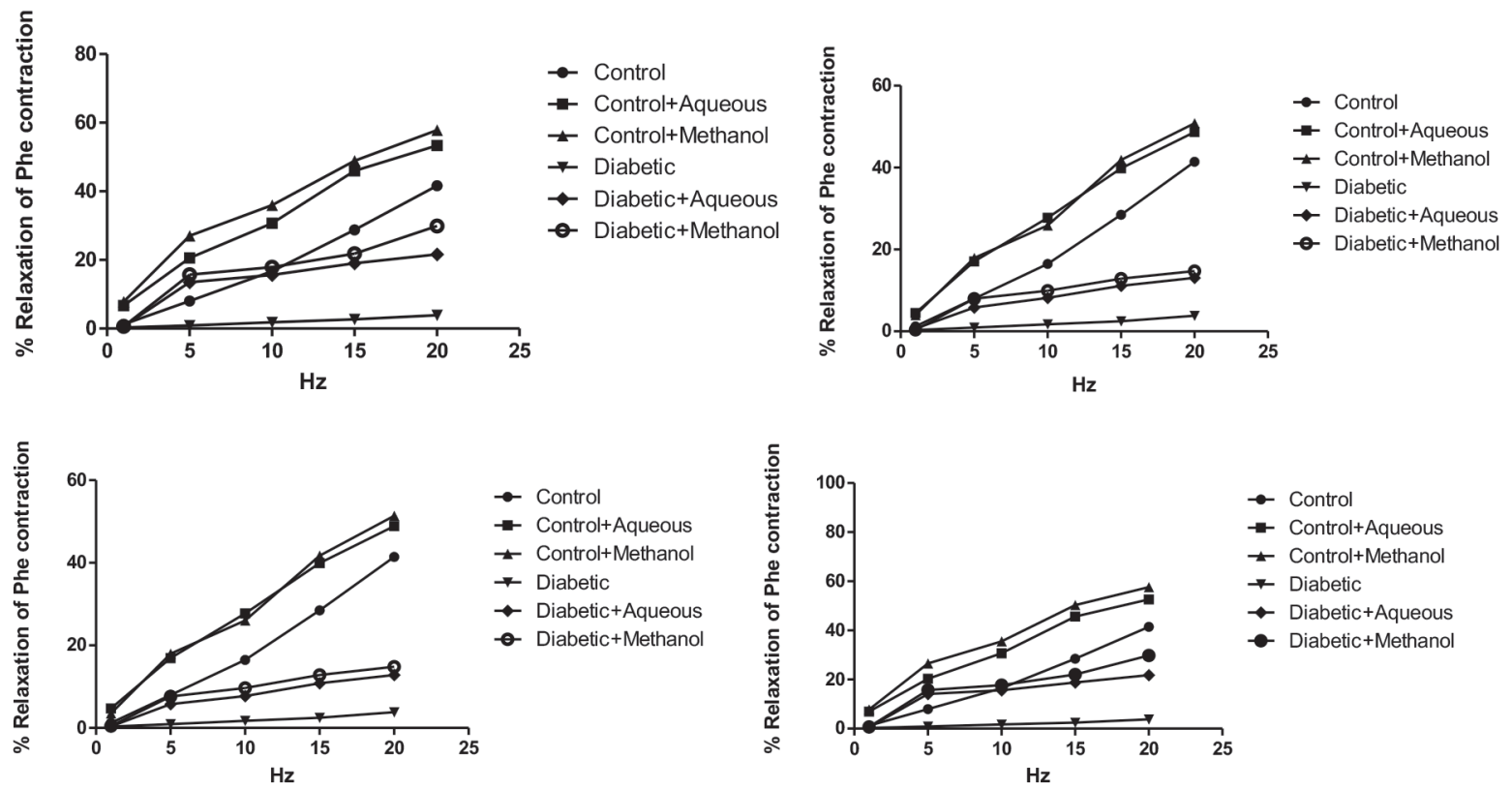

In the present study, relaxation responses to the PDE-5 inhibitor sildenafil in CC strips were lower in the diabetic rats than in the control rats. There was no difference in relaxant response to sildenafil between the control and diabetic rats' CC after incubation of the extracts. This finding indicates that these species have a potential effect on penile function by means of various pathways to contribute to erectile function in diabetic rats.

As shown in Figure 1, among the extracts, the methanol extracts of roots (especially roots of $F$. bracteata) showed the best activity. On the other hand, lyophilized aqueous extracts
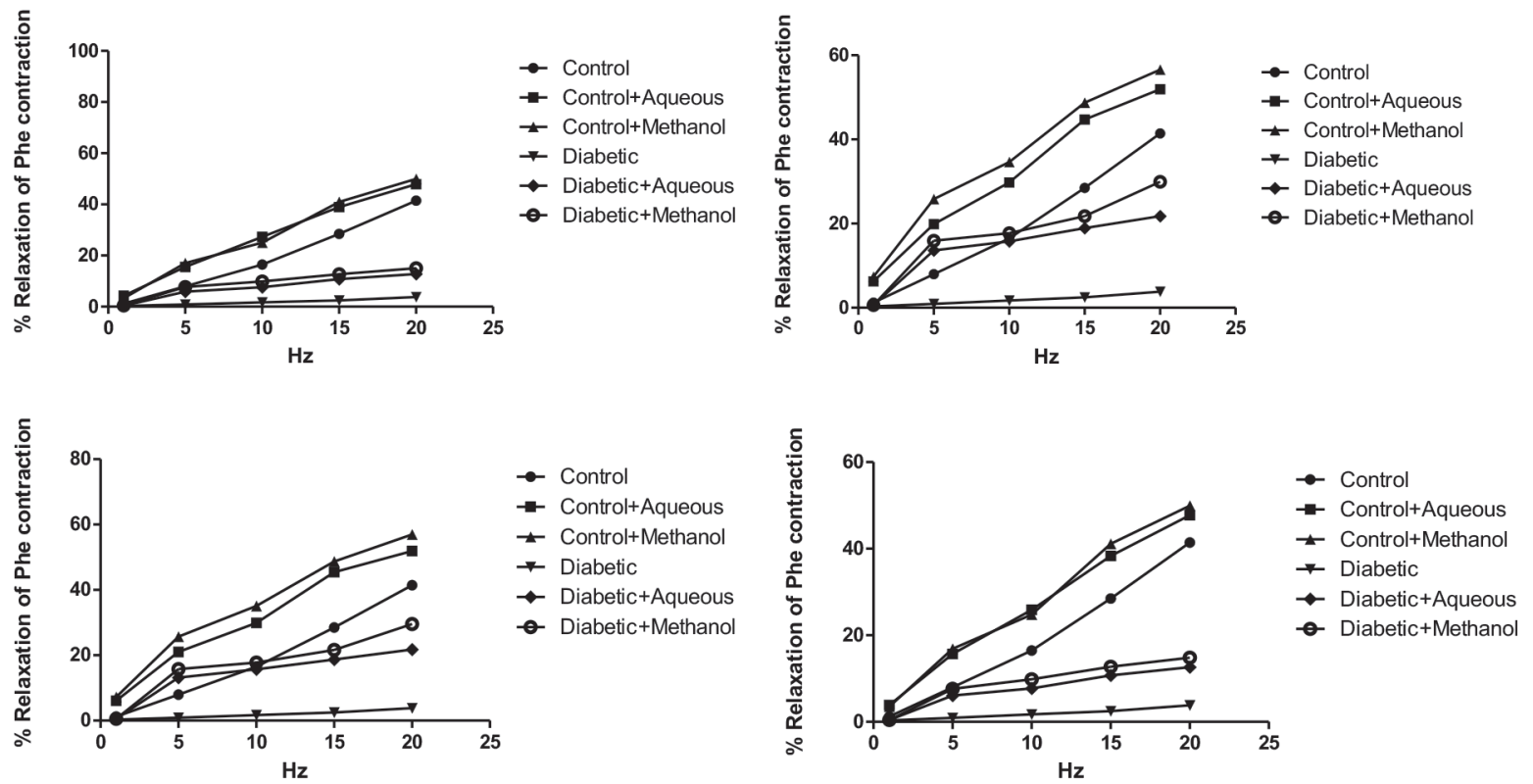

Figure 5. Relaxation responses to single doses of EFS in the presence of extract of FBIR, FBIH, FPR, FPH, FTR, FTH, FBrR, and FBrh, respectively. Data represent mean \pm standard error of mean of $6-8$ observations. ${ }^{*} p<0.05,{ }^{* \star *} p<0.001$ vs control value. $\S p<0.05, \S \S p<0.01$ vs diabetic value

EFS: Electrical field stimulation, FBIR: Root of F. blancheana, FBIH: Aerial part of F. blanchean, FPR: Root of F. pachyloba, FPH: Aerial part of $F$. pachyloba, FTR: Root of $F$. trachycarpa, FTH: Aerial part of $F$. trachycarpa, $\mathrm{FBrR}$ : Root of $F$. bracteata, $\mathrm{FBrH}$ : Aerial part of $F$. bracteate 
of the aerial parts (especially F. blancheana) showed the worst activity. EFS relaxation responses decreased from $40 \%$ in the controls rats to $3 \%$ in the diabetes rats. However, as a result of 15-min incubation of the extracts, the EFS relaxation responses increased to $21 \%$. Similarly, acetylcholine relaxation responses decreased from $38 \%$ in the controls to $13 \%$ in the diabetic rats. However, as a result of 15 -min incubation of the extracts, acetylcholine relaxation responses were increased by $40 \%$ and were higher than those in the controls. Sildenafil relaxation responses were $92 \%$ in the controls and $74 \%$ in the diabetic rats, but, as a result of 15 -min incubation of the extracts, acetylcholine relaxation responses were increased by
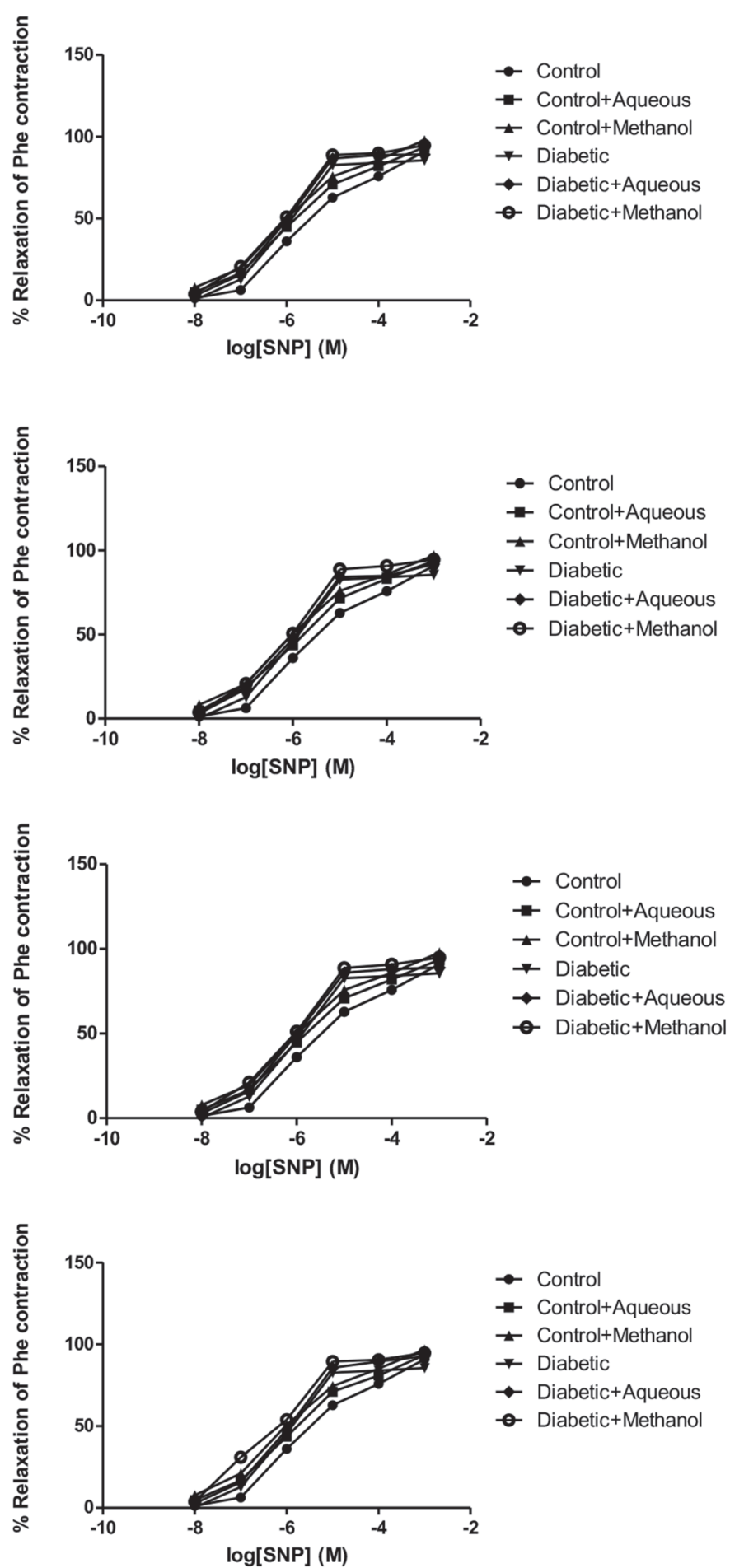
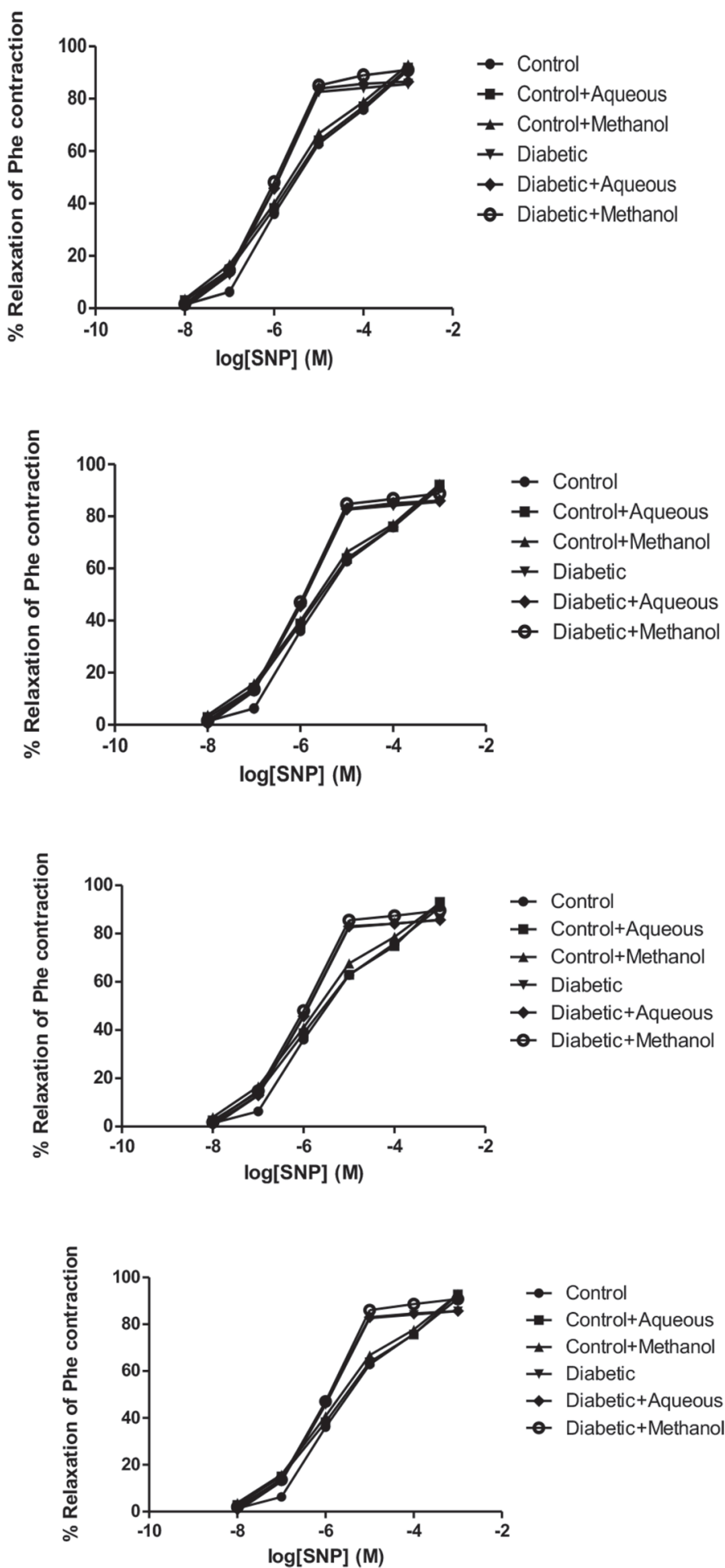

Figure 6. Relaxation responses to single doses of SNP in the presence of extract of FBIR, FBIH, FPR, FPH, FTR, FTH, FBrR, and FBrh, respectively. Data represent mean \pm standard error of mean of $6-8$ observations. ${ }^{*} p<0.05,{ }^{* \star *} p<0.001$ vs control value. $\S p<0.05, \S \S p<0.01$ vs diabetic value

SNP: Sodium nitroprusside, FBIR: Root of F. blancheana, FBIH: Aerial part of F. blanchean, FPR: Root of F. pachyloba, FPH: Aerial part of F. pachyloba, FTR: Root of $F$. trachycarpa, FTH: Aerial part of $F$. trachycarpa, FBrR: Root of $F$. bracteata, $\mathrm{FBrH}$ : Aerial part of $F$. bracteate 
95\% and were higher than those in the controls. SNP relaxation responses were $90 \%$ in the controls and $85 \%$ in the diabetic rats. However, as a result of 15-min incubation of the extracts, acetylcholine relaxation responses were increased by up to $94 \%$ and were higher than those in the controls. The results are shown in Figures 1-7.
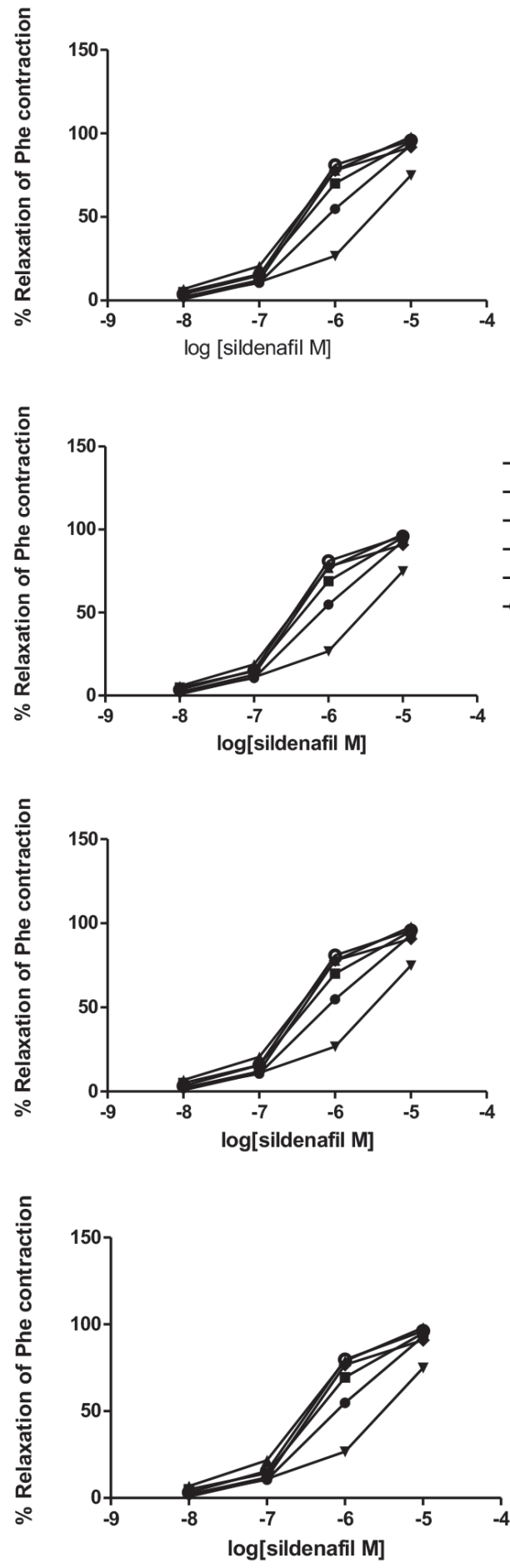

$\rightarrow$ Control

$\rightarrow$ Control+Aqueous

- Control+Methanol

* Diabetic

$\rightarrow$ Diabetic+Aqueous

- Diabetic+Methanol

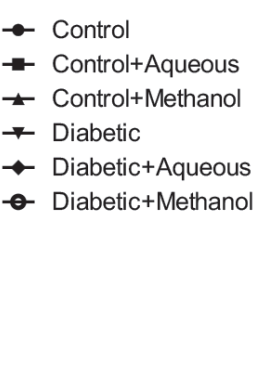

$\rightarrow$ Control+Aqueous

- Control+Methano

Diabetic

$\checkmark$ Diabetic+Aqueous

Diabetic+Methanol

$\rightarrow$ Control

- Control+Aqueous

- Control+Methanol

$\rightarrow$ Diabetic

$\rightarrow$ Diabetic+Aqueous

- Diabetic+Methanol

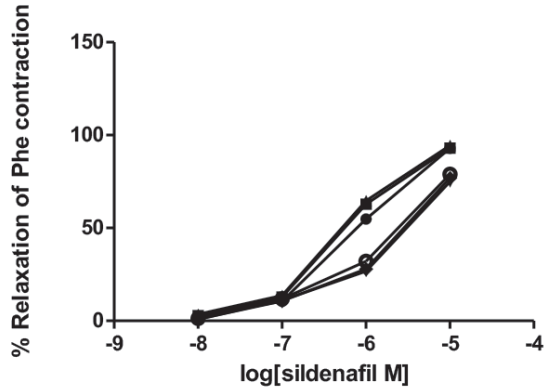

- Control

- Control+Aqueous

- Control+Methano

* Diabetic

$\rightarrow$ Diabetic+Aqueous

- Diabetic+Methanol
- Control

- Control+Aqueous

- Control+Methanol

$\rightarrow$ Diabetic

$\rightarrow$ Diabetic+Aqueous

- Diabetic+Methanol
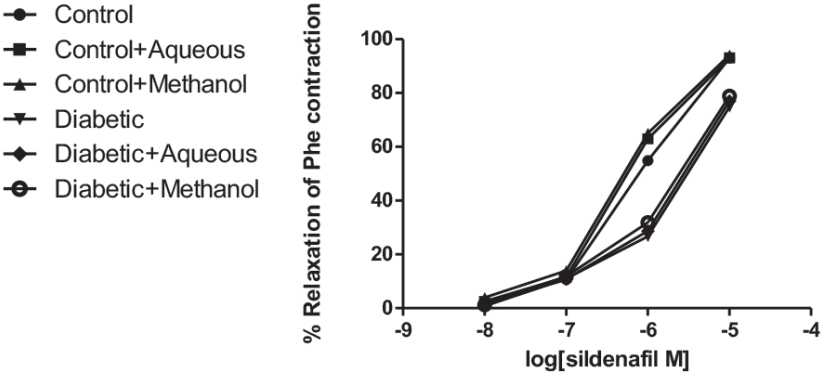

Control

- Control+Aqueous

- Control+Methanol

$\rightarrow$ Diabetic

$\checkmark$ Diabetic+Aqueous

- Diabetic+Methanol

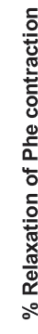

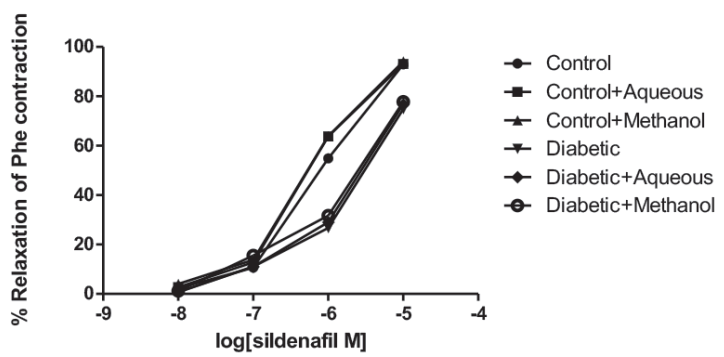

Figure 7. Relaxation responses to single doses of sildenafil in the presence of extract of FBIR, FBIH, FPR, FPH, FTR, FTH, FBrR and FBrh, respectively. Data represent mean \pm standard error of mean of $6-8$ observations. ${ }^{*} p<0.05,{ }^{* * *} p<0.001$ vs control value. $\S p<0.05, \S \S p<0.01$ vs diabetic value

FBIR: Root of F. blancheana, FBIH: Aerial part of F. blanchean, FPR: Root of F. pachyloba, FPH: Aerial part of $F$. pachyloba, FTR: Root of $F$. trachycarpa, FTH: Aerial part of F. trachycarpa, FBrR: Root of F. bracteata, $\mathrm{FBrH}$ : Aerial part of F. bracteate 


\section{CONCLUSIONS}

The present study primarily revealed the useful effect of intracavernosal administration of extracts in improving erectile function in diabetic rats, which is dependent on the NO/cGMP pathway. The preclinical findings should extend our information of the beneficial effects of the extracts on penile function to develop preventive or therapeutic agents and combinations of them, and phosphodiesterase- 5 inhibitors may be a beneficial option for diabetes-induced ED.

\section{ACKNOWLEDGEMENTS}

This study was supported by the Scientific and Technological Research Council of Turkey (TUBITAK 115S009).

Conflict of Interest: No conflict of interest was declared by the authors.

\section{REFERENCES}

1. Mazzilli R, Elia J, Delfino M, Benedetti F, Scordovillo G, Mazzilli F. Prevalence of Diabetes Mellitus (DM) in a population of men affected by Erectile Dysfunction (ED). Clin Ter. 2015;166:317-320.

2. Rastrelli G, Corona G, Mannucci E, Maggi M. Vascular and Chronological Age in Subjects with Erectile Dysfunction: A Cross-Sectional Study. J Sex Med. 2015;12:2303-2312.

3. Johannes CB, Araujo AB, Feldman HA, Derby CA, Kleinman KP, Mckınlay JB. Incidence of erectile dysfunction in men 40 to 69 years old: longitudinal results from the Massachusetts male aging study. J Urol. 2000;163:460-463.

4. Ruan Y, Li M, Wang T, Yang J, Rao K, Wang S, Yang W, Liu J, Ye Z. Taurine Supplementation Improves Erectile Function in Rats with Streptozotocin-induced Type 1 Diabetes via Amelioration of Penile Fibrosis and Endothelial Dysfunction. J Sex Med. 2016;13:778-785.

5. Baytop T. Therapy with Medicinal Plants in Turkey-Past and Present ( $2^{\text {nd }}$ ed). Istanbul; Nobel Medical Publ; 1999.
6. Ibrahim JA, Muazzam I, Jegede IA, Kunle OF. Medicinal plants and animals sold by the "Yan-Shimfidas" of Sabo Wuse in Niger State, Nigeria. Afr J Pharm Pharmacol. 2010;4:386-394.

7. Erdurak CS. Investigations on Ferulago isaurica Peșmen and F. syriaca Boiss. (Umbelliferae) species. Ankara; Ankara University, PhD thesis; 2003.

8. Güner A. Türkiye Bitkileri Listesi (Damarlı Bitkiler), Flora Dizisi .1 (1st ed). İstanbul; Nezahat Gökyiğit Botanik Bahçesi Publ; 2012:62-64.

9. Davis PH. Flora of Turkey and the East Aegean Islands (4th ed). Edinburgh; University Press; 1972:4;462-464.

10. Yilmaz Oral D, Bayatli N, Gur S. The Beneficial Effect of Fesoterodine, a Competitive Muscarinic Receptor Antagonist on Erectile Dysfunction in Streptozotocin-induced Diabetic Rats. Urology. 2017;107:271.

11. Ozturk B, Gur S, Coskun M, Kosan M, Erdurak CS, Hafez G, Gonulalan $U$, Cetinkaya M. A new relaxant on human corpus cavernosum: Ferulago syriaca root extract. Afr J Pharm Pharmacol. 2012;6:2652-2656.

12. Garud MS, Kulkarni YA. Attenuation of renal damage in type I diabetic rats by umbelliferone - a coumarin derivative. Pharmacol Rep. 2017;69:1263-1269.

13. Ramu R, S Shirahatti P, S NS, Zameer F, Lakkappa Dhananjaya B, M N NP. Assessment of In Vivo Antidiabetic Properties of Umbelliferone and Lupeol Constituents of Banana (Musa sp. var. Nanjangud Rasa Bale) Flower in Hyperglycaemic Rodent Model. PLoS One. 2016;11:e0151135.

14. Gao D, Zhang YL, Xu P, Lin YX, Yang FQ, Liu JH, Zhu HW, Xia ZN. In vitro evaluation of dual agonists for PPAR $/ \beta$ from the flower of Edgeworthia gardneri (wall.) Meisn. J Ethnopharmacol. 2015;162:14-19.

15. Cengiz T, Kaya E, Oral DY, Ozakca I, Bayatli N, Karabay AZ, Ensari TA, Karahan T, Yilmaz E, Gur S. Intracavernous Injection of Human Umbilical Cord Blood Mononuclear Cells Improves Erectile Dysfunction in Streptozotocin-Induced Diabetic Rats. J Sex Med. 2017;14:50-58.

16. Yilmaz D, Bayatli N, Un O, Kadowitz PJ, Sikka SC, Gur S. The effect of intracavernosal avanafil, a newer phosphodiesterase- 5 inhibitor, on neonatal type 2 diabetic rats with erectile dysfunction. Urology. 2014:83:508. 